\title{
Ethanol inhibits acetate metabolism in rat hepatocytes
}

Quistorff, Bjørn; Knudsen, Charlotte T.; Grunnet, Niels

Published in:

Basic \& Clinical Pharmacology \& Toxicology

Publication date:

1995

Document version

Publisher's PDF, also known as Version of record

Citation for published version (APA):

Quistorff, B., Knudsen, C. T., \& Grunnet, N. (1995). Ethanol inhibits acetate metabolism in rat hepatocytes.

Basic \& Clinical Pharmacology \& Toxicology, 76(2), 133-135. 


\title{
Ethanol Inhibits Acetate Metabolism in Rat Hepatocytes
}

\author{
Chariotte T. Knudsen, Bjørn Quistorff and Niels Grunnet \\ Department of Medical Biochemistry and Genetics, Biochemistry Laboratory A, The Panum Institute, University of \\ Copenhagen, Blcgdamsvej 3, DK-2200 Copenhagen N, Denmark
}

(ReceivedMay 19, 1994; Accepted August 31, 1994)

\begin{abstract}
The metabolism of acetate at concentrations of $1,2.5,5$ and $10 \mathrm{~mm}$. was investigated in freshly isolated hepatocytes from $48 \mathrm{hr}$ fasted, female rats in the absence and presence of $10 \mathrm{mM}$ ethanol. The maximal capacity for acetate metabolism was $0.85 \mu \mathrm{moV}\left(10^{8}\right.$ cells $\left.\cdot \mathrm{min}\right)$. Ethanol caused a $20 \%$ decrease in the apparent $\mathrm{V}_{\max }$ [or acetate metabolism and an increase in the apparcnt $K_{m}$ for acetate from 3.0 to $4.6 \mathrm{mM}$. At physiological concentration of acetate ( $\sim \mathrm{I} \mathrm{mM}$ ) and in the absence of an inhibitory effect of ethanol, the capacity for acetate metabolism was $15-20 \%$ of the rate of acetate formation from ethanol and the inhibitory effeet of cthanol further reduced it to $10-15 \%$. The results thus explain the well-known but hitherto not understood fact that only a small fraction of acetate produced in the liver during ethanol oxidation is further metabolized by the liver, while the majority is exported for oxidation in other tissues. Finally, a new method for caleulation of liver acclate uptake in the presence of cthanol is presented.
\end{abstract}

The metabolism of alcohol in the liver has been studied extensively for almost a century and in fact, at some point in the sixties and early seventies, the unravelling of intermediary metabolism had alcohol oxidation as one of its central themes. Consequently, most aspects of alcohol metabolism is well understood with rather few open questions. One of these are, however, why the liver takes up only a small fraetion of the acetate produced during ethanol metabolism, in spite of the fact that there is significant activity of the enzyme acetyl-CoA synthetase (Forsander et al. I960; Lundquist et al. 1962; Williamson et al. 1969; Fellenius \& Kiessling 1973). It should be noted, however, that there are considerable disagreement about the capacity of this enzyme, and values between 0.2 to 3 units per $g$ liver wet weight has been reported, corresponding to 20 to $90 \%$ of the rate of acetate production by ethanol oxidation (Aas 1971; Barth et al. 1971; Fellenius et al. 1973; Knowles et al. 1974). Direct inhibition of acetate metabolism during ethanol oxidation has never been demonstrated.

The present work was undertaken to elucidate these questions. We find that acetate metabolism is in fact inhibited by ethanol, and that the capacity of hepatocytes for acetate metabolism is low eompared to the rate of ethanol oxidation.

\section{Materials and Methods}

Cell preparations. Hepatocytes werc isolated from female Wistar rats $(230 \mathrm{~g}$ ) fasted for $48 \mathrm{hr}$ by collagenase perfusion (Quistorff et al. 1990). The cells were suspended to a final concentration of 5-7* $10^{6} \mathrm{cclls} / \mathrm{ml}$ in Krebs-Henseleit buffer with $10 \mathrm{mM}$ lactate, $2 \mathrm{mM}$ pyruvatc and $1 \%$ bovinc serum albumin.

Author for correspondence: Niels Grunnet, Biochemistry Laboratory A, Panum Institute, Blegdamsvej 3, DK-2200 Copenhagen N, Denmark (fax +4535327701$)$.
Incubations. $1.9 \mathrm{ml}$ of the cell suspension was incubated with shaking ( 80 strokes $/ \mathrm{min}$ ) in $25 \mathrm{ml}$ flasks with filter papers in centerwells. The gas phase was $95 \% \mathrm{O}_{2} / 5 \% \mathrm{CO}_{2}$. After 15 min. preincubation at $37^{\circ}$ the incubations were started at $\mathrm{t}=0$ by addition of $100 \mu$ acetatc and cthanol mixturc. The final concentrations in the incubations were $1,2.5,5$ and $10 \mathrm{mM}\left[2-{ }^{14} \mathrm{C}\right] \mathrm{NaAcetate}(12,000 \mathrm{dpm} / \mu \mathrm{mol})$ and when present $10 \mathrm{mM}$ ethanol. This concentration of ethanol ensurcd saturation of alcohol dehydrogenase. Incubations were performed in duplicale and with parallel incubations without cells.

The incubations were stopped after $30 \mathrm{~min}$. by addition of perchloric acid to a final concentration of $0.7 \mathrm{M} .125 \mu \mathrm{l}$ of $4 \mathrm{~N} \mathrm{NaOH}$ was added to the filter papers and the flasks were allowed to stand for $\mathrm{I} \mathrm{hr}$ at $37^{\circ}$ with shaking to collect ${ }^{14} \mathrm{CO}_{2}$. The filter papers were transferred to tubes with $2 \mathrm{ml}$ of water. The day after the incubations the filter papers were removed and the radioactivity of $1 \mathrm{ml}$ of the water was determined. The acidified cell suspensions were centrifuged and the pellets were used for determination of ${ }^{14} \mathrm{C}$ in fatty acids. The supernatants were used for determination of ${ }^{14} \mathrm{C}$ in non-volatilc, water soluble products and, after neutralization with $\mathrm{KOH}$ and triethanolamine for metabolite determinations.

Metabolite assays. To measure the ${ }^{14} \mathrm{C}$ incorporation in fatty acids the perchloric acid precipitate was washed 3 times in $2 \mathrm{~N}$ perchloric acid and twice in watcr, dissolved in $\mathrm{NaOH}$, and the radioactivity determincd. To measure the ${ }^{14} \mathrm{C}$ incorporation in tricarboxylic acid cycle intermediates, ketone bodies, and other non-wolaule components, remaining $\left[2-{ }^{14} \mathrm{C}\right]$ acetate was removed by freeze-drying of the perchloric acid extracts. The amount of $\left[2-{ }^{14} \mathrm{C}\right]$ acetate was calculated as the total radioactivity in the perchloric acid extracts minus the radioactivity of the freeze-dried perchloric acid extracts.

Acetate (Holz \& Bergmeyer 1970), ethanol (Lundquist 1959), 3hydroxybutyrate (Williamson \& Mellanby 1970), and lactate (Hohorst 1970), were measurcd ising enzymatic assays on the neutralized perchloric acid supernatants. Pyruvate and acetoacetate werc measured in a combined enzymatic assay in $0.2 \mathrm{M}$ TRIS, pH7.6 (Mellanby \& Williamson 1970).

Calculations. At high concentrations of acetate, and especially in the presence of ethanol, the chemically measured uptake of acetate becomes unreliable due to the small, relative change in the concentration of acetate. Acetate metabolism was therefore determined as incorporation of $\left[2-{ }^{4} \mathrm{C}\right]$ acetate into products. Acetate uptake in the absence of ethanol as determined by measurements of the concen- 
trations before and after the incubations was $85-116 \%$ of the [2${ }^{14} \mathrm{Clacetate}$ incorporation into products.

When ethanol is metabolized in the celis, the acetate pool is diluted by acetate produced from ethanol. and the specific radioactivity of acetate falls exponentially during the incubation period. Furthermore, the acetate concentration rises, causing an increase in the rate of acetate metabolism at lower-than-saturating acerate concentrations.

In order to calculate the mean specific radioactivity of acetate during the incubation, an iterative procedure was worked out as described below:

The mean of the specific radioactivity at the beginning and at the end of the incubations were used as a first approximation. The rate of acetate metabolism was caiculatcd from this approximated specific radioactivity and the incorporation of radioactivity into products. The rates of acetate metabolism and the corresponding mean acetate concentrations were subsequently used for calculation of the apparent $\mathrm{K}_{\mathrm{m}}$ and $\mathrm{V}_{\max }$ for the metabolism of $\left[2{ }^{14} \mathrm{C}\right] \mathrm{ace}$ ate. The values were then used in a stepwise calculation of the time-course of the acetate concentration and the specific radioactivity of acetate during the $30 \mathrm{~min}$. incubation:

(1) [acetate $]_{t+\Delta t}=[\text { acetate }]_{1}+\Delta[\text { ethanol }]_{\Delta t}-\Delta[\text { acetate }]_{\Delta t}$

where square brackets indicate concentrations at time $t$ and $t+\Delta t$, respectively. $\Delta[\text { acetate }]_{\Delta t}$ was obtained from the Michaelis-Menten equation using the $\mathrm{K}_{m}$ and $\mathrm{V}_{\mathrm{mnx}}$ values obtained above:

(2) $\Delta[\text { acetate }]_{\Delta_{1}}=\Delta t\left(V_{\text {max }}[\text { acetate }]_{l} /\left([\text { acetate }]_{l}+K_{m}\right)\right.$

The specific radioactivity of acetate at time $t+\Delta t\left(S_{\text {acetate. } b+\Delta t}\right)$ equals total radioactivity of acetate at time $t+\Delta t\left(R_{\text {acetare } t+\Delta t}\right)$ djvided by [acetate] $]_{1+\Delta I}$ (as obtained from equation (1)):

(3) $S R_{\text {actatse, } t+\Delta t}=\left(R_{\text {acstute.t }+\Delta t}\right) /[\text { acetate }]_{t+\Delta t}$

where $\left(R_{\text {acctate, },+\Delta t}\right)$ was calculated as $\left(R_{\text {acelate },}\right)-\left(\Delta R_{\text {acetare, } \Delta 1}\right)$, in which $\Delta R_{\text {aceetuce, } \Delta \text { i }}$ was obtained by multiplication of the specific radioactivity of acetate at time $t$ by the change in acetate concenIration in $\Delta t$ (from equation (2)).

After 3 to 4 iterations using $\Delta t=2 \mathrm{~min}$, a constant mean specific radioactivity of acetate was obtained. This value was then used for calculation of the rate of acetate metabolism.

The calculated specific radioactivity of acetate was about 19\% less than the mean value of the specific radioactivity at the start and at the end of the incubations. The best fit was abtained when the rate of ethanol oxidation was $1.4 \mu \mathrm{mol} /\left(10^{8} \mathrm{cells} \cdot \mathrm{min}\right.$.). Changes in $V_{\max }$ and $K_{m}$-values had only minor influence on the resuits of the calculations. The acetate concentrations used in fig. 1 are the means of the experimentally determined concentrations before and after the incubations. The error on this values as compared to that calculated by the iterative procedure was negligable $(<1 \%)$.

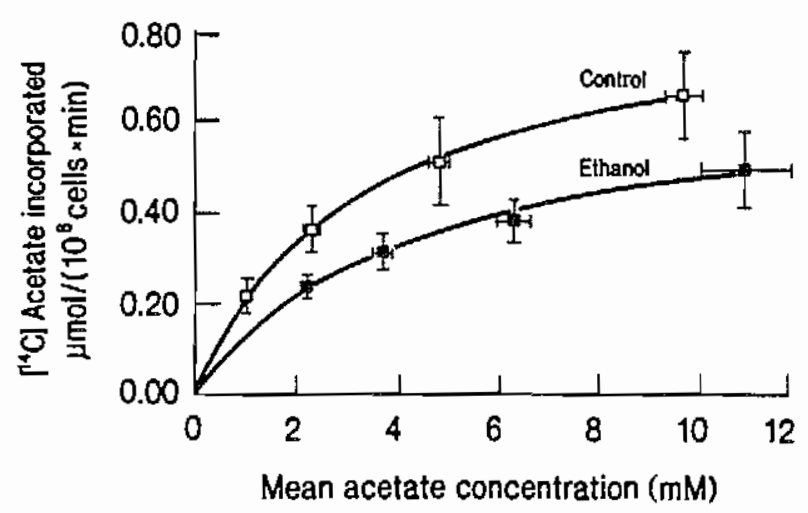

Fig. $1 .{ }^{14} \mathrm{C}$-Incorporations from $\left[2-{ }^{14} \mathrm{C}\right]$ acetate into metabolic products in the presence and absence of ethanol. Values are means $\pm S . D$.

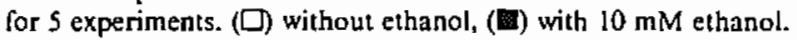

Apparent $K_{m}$ 's for acetate and $V_{\max }$ 's of $\left[2-{ }^{14} C\right]$ acetate metabolism were calculated from Lineweaver-Burk plors by linear re. gression with proportional weighting.

Statistics. $\mathrm{K}_{\mathrm{m}}$ 's and $\mathrm{V}_{\mathrm{max}}$ 's in the presence and absencc of ethanol were compared by paired-data t-test. All values given are means $\pm S$. D. with the number of animals in parenthesis.

\section{Results and Discussion}

Fig. I shows the incorporation of ${ }^{14} \mathrm{C}$ from $\left[2-{ }^{14} \mathrm{C}\right]$ acetate into metabolic products at different concentrations of acetate in the presence and absence of ethanol. The metabolism of $\left[2 .{ }^{14} \mathrm{C}\right]$ acetate appeared to follow Michaëlis-Menten kinetics with an apparent $\mathrm{K}_{\mathrm{m}}$ for acetate of $3.02 \pm 0.37 \mathrm{mM}$ and an apparent $V_{\max }$ of $0.845 \pm 0.118 . \mu \mathrm{mol}\left(10^{8}\right.$ cells $\cdot \min$. $)$ in the absence of ethanol. In the presence of ethanol, $\mathrm{K}_{\mathrm{m}}$ for acetate was increased to $4.06 \pm 1.34 \mathrm{mM}$, while there was a statistical significant decrease in $\mathrm{V}_{\max }$ to $0.662 \pm 0.148 \mu \mathrm{mol} /$ $\left(10^{8}\right.$ cells $\cdot \min$.) $(P<0.05, n=5)$. The inhibition of acetate metabolism at $1 \mathrm{mM}$ acetate by ethanol was $36 \% \pm 7 \%$.

The incorporation of $\left[2-{ }^{14} \mathrm{C}\right]$ acetate into non-volatile water soluble products and carbon dioxide was inhibited by $40 \%$ and $60 \%$, respectively by ethanol at $1 \mathrm{mM}$ acetate. The incorporation of $\left[2 .{ }^{14} \mathrm{C}\right]$ acetate into fatty acids was enhanced two-fold in the presence of ethanol (results not shown).

In accordance with established results (Forsander ef al. 1965; Williamson et al. 1969), the lactate/pyruvate and 3hydroxybutyrate/acetoacetate ratios were $3.13 \pm 0.07$ and $1.09 \pm 0.40$ in the absence of ethanol and increased to $38.0 \pm 16.6$ and $3.12 \pm 0.18$ in the presence of ethanol $(n=5)$. There was no dependency on the concentration of acetate, except for a slight increase in the lactate/pyruvate ratio with increasing acetate concentrations in the absence of ethanol $(2.69 \pm 0.01$ and $3.49 \pm 0.19$ at 1.0 and $9.7 \mathrm{mM}$ acetate, respectively). Total ketone body formation was unchanged (results not shown). The rate of oxidation of ethanol was in the range $0.74-1.14 \pm 0.25 \mu \mathrm{moV}\left(10^{8}\right.$ cells $\left.\cdot \min .\right)(n=4)$.

A possible explanation for the inhibition of acetate metabolism by ethanol could be the well known fall in tricarboxylic acid cycle flux (Williamson et al. 1969; Lindros 1972) during ethanol oxidation combined with an unaltered ketone body synthesis (Grunnet \& Kondrup 1983; present study). Since the oxidation of acetyl-CoA in the TCA-cycle has a low apparent $V_{\max }$ and in particular a low $\mathrm{K}_{\mathrm{m}}$ compared with ketone body synthesis (Ontko \& Jackson 1964), a decrease of the tricarboxylic acid cycle fux would result in a lower apparent $\mathrm{V}_{\max }$ and a higher apparent $\mathrm{K}_{\mathrm{m}}$ for acetate uptake, as observed. The possibility that the relatively small oxidation of ethanol-generated acetate in the liver could be caused by metabolic zonation with a predominant location of the cytosolic acety! CoA synthetase in the upstream part of the sinusoids has been discarded in a recent study (Knudsen et al. 1992).

The concentration of acetate in the hepatic vein is about $1 \mathrm{mM}$ during ethanol metabolism (Lundquist et al. 1962; Nuutinen ef al. 1985). Based on the $K_{m}$ and $V_{\max }$ values 
above. the capacity for acetate merabolism at this conceniration of acetate can be calculated to 0.21 and $0.13 \mu \mathrm{mol} /$ ( $10^{x}$ cells $\left.\cdot \min .\right)$ in the abscnce and presence of ethanol. respectively, which can be compared to a rate of acetate formation irom ethanol of $1-1.5 \mu \mathrm{mol} /\left(10^{8} \mathrm{cells} \cdot \mathrm{min}\right.$.). In conclusion. the present results show that the small fractional metabolism of acctate by the liver during ethanol oxidation is due primarily to a low capacity of hepatocytcs for acetate metabolism with a minor contribution from inhibition of acetatc metabolism by ethanol.

\section{Acknowledgements}

This research was supported by grants from "Fonden til Lagevidenskabens Fremme".

\section{Referenees}

Aas, M.: Organ and subcellular distribution of fatty acid activating cnzymes in the rat. Biochim. Biophys. Actu 1971, 231, 32-47.

Barth, C., M. Sladek \& K. Decker: The subcellular distribution of short-chain fatty acyl-CoA synthetase activity in rat tissues. Biachim. Biophys. Acta 197I, 248, 24-33.

Fellenius, E. \& K.-H. Kiessling: Effect of cthanol on fatty acid oxidation in the perfnsed livers of starved, fed. and fat-fed rats. Acta chem. scond. 1973, 27, 2781-2790.

Fellenius, E., U. Nisbeth, L. Pilström \& K.-H. Kiessling: Changes in the activity of citrate lysase, malic enzyme and aectyl-CoA synthetase in rat liver after short- and long-term feeding with ethanol. Brit. J. Nutr. 1973, 29, 307-316.

Forsinder, O., N. Räihä \& H. Suomalainen: Oxydation des Äthylalkohols in isolierter Leber und isoliertem Hinterkörper der Ratle. Hoppe-Seylers Z. Physiol, Chemie [960, 318, 1-5,

Forsander, O. A., N. Rảihä, M. Salaspuro \& P. Mäenpäă: Influenec of ethanol on the liver metabolism of fed and starved rats. Biochem. J. 1965, 94, 259-265.

Grunnet, N. \& J. Kondrup: Effect of ethanol, noradrenaline and $3^{\prime}, 5^{\prime}$-cyclic AMP on oxidation of fatty acids and lipolysis in iso- lated rat hepatocyics. Phurmacol. Biochem. Behav. 1983. I8 suppl $1,2+5-250$.

Hohorst, H.-J.: L-(+)-dactal. Bestimmung mit Lactal-Dehydrogenase und NAD. In: .lethoden der enzymatischen Analyse, vol. 2. Ed.: H. U. Bergmeyer. Verlag Chemie, Weinheim. 1970. 14251429.

Holz, G. \& H. U. Bergmeyer: Acctate. Bestimmung mit Acetal Kinase und Hydroxylamin. In: Methoden der enzymatischen Analyse, vol. 2. Ed.: H. U. Bergmeyer. Verlag Chemic, Weinheim, 1970. $1486-1490$.

Knowles, S. E., I. G. Janett, O. H. Filsell \& F. J. Ballard: Production and utilization of acetate in mammals. Biochem. J. 1974, 142, 40 I- -11 I.

Knudsen, C. T., L. Immerdal, N. Grunnet \& B. Quistorîf: Periportal zonation of the cytosolic acetyl-CoA synthetase of male rat liver. Eur. J. Biochem, 1992, 204. 359-362.

Lindros, K. O.; Role of the redox state in ethanol-induced suppression of citrate-cycle flux in the perfused liver of normal. hyper- and hypothyroid rats. Eur. $J$, Biochem. 1972, 26, 338-346.

Lundquist, F.: The determination of ethyl alcohol in blood and tissues. Meth, Biochem. Anal. 1959, 7, 217-251.

Lundquist, F., N. Tygstrup, K. Winkler, K. Mellemgaard \& S Munck-Petersen: Ethanol metabolism and production of free acetate in the human liver. $J$. Clin. Invest. 1962, 41, 955-961.

Mellanby, J. \& D. H. Williamson: Acetacetat. In: Methoden der enzymatischen Analyse, vol. 2. Ed.: H. U. Bergmeyer. Verlag Chemie, Weinheim, 1970, 1776-1779.

Nuutinen, H., K. Lindros, P. Hekali \& M. Salaspuro: Elevated blood acctate as indicator of fast ethanol climination in chronic alcoholics. Alcohol $1985,2,623-626$.

Ontko, J. A. \& D. Jackson; Factors affecting the rate of oxidation of fatty acids in animal tissues. J. Biol. Chem. 1964, 239, 36743682.

Quistorff, B., J. Dich \& N. Grunnet: Preparation of isolated rat liver hepatocytes. In: Methods in molecular biology, vol. 5. Eds.: J. W. Pollard and J. M. Walker. The Hnmana Press, Clifton, 1990 , $15 !-160$.

Williamson, D. H.\& J. D. Mellanby; 3-Hydroxybutyrat, In: Methoden der enzymatischen Analyse, vol. 2. Ed.: H. U. Bergmeyer. Verlag Chcmie, Weinheim, 1970, 1771-1775.

Williamson, J. R., R. Scholz, E. T. Browning, R. G. Thurman \& M. H. Fukami: Metabolic effects of ethanol in perfused rat liver. $J$. Bial. Chem. 1969, 244, 5044-5054. 